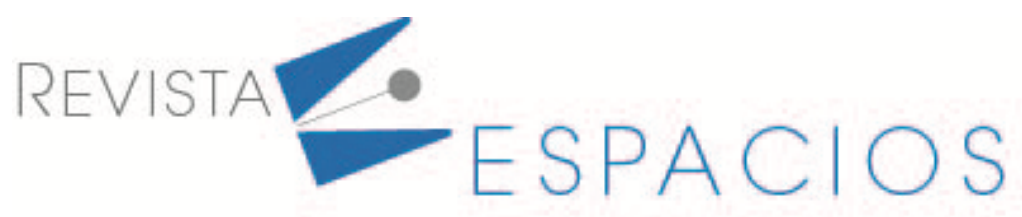

\title{
Reduction of inequalities in Colombia according to Sustainable Development Goal 10
}

\section{Reducción de desigualdades en Colombia según el objetivo del desarrollo sostenible 10}

\author{
REDONDO, Marlen I. ${ }^{1}$ \\ DUQUE, Cristian C. ${ }^{2}$ \\ DIAZ, Carlos A. ${ }^{3}$ \\ RODRIGUEZ, Laura J. ${ }^{4}$
}

\begin{abstract}
This is a bibliographic review article on the reduction of inequalities in Colombia, focused on the Sustainable Development Goal 10, which is related to the National Development Plan of Colombia for the period 2010-2014 in order to identify the policies and programs developed in the country. It can be concluded that Colombia has been improving social conditions from early childhood and contributing to the formation of future generations; nevertheless Colombia still falls short in its education coverage.

key words: inequality, education, Sustainable Development Goals,socialprograms.

\section{Resumen}

Este es un artículo de revisión bibliográfica sobre las reducción de las desigualdades en Colombia, centrado en el Objetivo del Desarrollo Sostenible 10, que está relacionado con el Plan Nacional de Desarrollo de Colombia para el año 2014 con el fin de identificar las políticas y programas desarrollados en el país. Se puede concluir que Colombia ha venido mejorando las condiciones sociales desde la primera infancia y ha contribuido a la formación de generaciones futuras; sin embargo, Colombia sigue atrasada en su cobertura en educación.

Palabras clave: desigualdad, educación, Objetivos del Desarrollo Sostenible, programas sociales.
\end{abstract}

\section{Introduction}

One can argue that the social inequalities are a critical phenomenon at large scale of the world's population. This text broach the subject of the Sustainable Development Goals (SDG) and the goals to be met by the member countries of the United Nations Organization, which are available on the website of the United Nations Development Program, the search was initially made from a quest for concepts on the Sustainable Development Goals, focusing on the development of the theme in the objective ten "Reduction of inequalities", evaluating a

\footnotetext{
${ }^{1}$ Director of Research Center, Faculty of Economic Administrative and Accounting Sciences, Universidad Libre de Colombia, Pereira. isabel.redondo@unilibre.edu.co

${ }^{2}$ Economics graduate of the Faculty of Economic Administrative and Accounting Sciences, Universidad Libre de Colombia, Pereira. cristianduqueg@unilibre.edu.co

${ }^{3}$ Doctoral student in Business administration, Universidad Nacional, Manizales, Colombia. Professor of the Faculty of Economic Administrative and Accounting Sciences, Universidad Libre of Colombia, Pereira, Colombia. carlos.diazr@unilibre.edu.co

${ }^{4}$ Economics Student, Faculty of Economic Administrative and Accounting Sciences, Universidad Libre de Colombia, Pereira. laurajrodriguezh@unilibre.edu.co
} 
serious problem that is growing increasingly in society, guiding internal policies in countries so that the gap in social, educational, economic and cultural aspects can be reduced. In the case of Colombia, the national government, through development plans and. For the specific case of this content, it has been chosen a development plan prior to the consolidation of the Sustainable Development Goals, this particular plan is the National Development Plan from 2010 to 2014, given that was one of the first government documents that brought to the table different inicitives that later would have become important seeds for Colombia's efforts towards keeping its part in the SDG. This development plan froexecuted guidelines focused on reducing inequalities with specific objectives. These objectives were developed through social programs and projects, which have public budgets and private social investments for the development of the most vulnerable populations and racial and ethnic groups in the country. This document sets out what the programs and the social contribution were to improve the standards of life quality not only from the income perspective but also from other important factors, such as health and education.

The goals of sustainable development, also known as World Goals, are a universal call for proper measures to end poverty, protect the planet, and ensure that all people enjoy peace and prosperity. There are currently 17 objectives based on the achievements of the Millennium Development Goals, although they include new areas, such as climate change, inequality in the economy, innovation, sustainable consumption, peace and justice, among other priorities (United Nations Development Programme, 2015).

The sustainable development tries to relate the complexity between economy and environment, economy and ecology; more strictly, economic development and environment. In other words, the development is sustainable if it improves the level and quality of human life and, at the same time, if it guarantees and preserves the natural resources of the planet (Vergara Tamayo \& Ortiz Motta, 2016).

The goal 10 "Reduction of inequalities" points out that inequality is increasing. The $10 \%$ of the wealthy population keeps $40 \%$ of the world income; while $10 \%$ of the poor population obtains between 2 and 7 percent of the total income (United Nations Development Programme, 2016).

According to the United Nations Development Program (2015), some relevant data produced by SDG 10 "Reduction of inequalities" are the following:

Children who are in the poorest $20 \%$ of the population have up to three times the possibility of dying before reaching the age of five, compared to children who are located in the wealthiest quintiles.

Countries, more than $64.4 \%$ of the products were exported to world markets with zero rates since 2016 compared to 2010 , when only $44.4 \%$ products were exported in this condition.

People who have disabilities are up to five times more likely to confront health expenditures, which are classified as catastrophic and this occurs even if they have a social protection that has spread throughout the world.

Inequality within households has been the reason why there is a $30 \%$ inequality of income between women and men. Likewise, the female gender is more likely to live below $50 \%$ of average income (minimum income) compared to the male gender.

There has been a general decrease in maternal mortality; however, in some developing countries there is up to three times probability that a woman in rural areas will die during childbirth than a woman who lives in urban centers.

In other words, what it is intended to be done with this objective is: "to boost and promote the social, economic and political inclusion of all people, regardless of their age, sex, disability, race, ethnicity, origin, religion or economic situation or other condition by 2030" (Cantú Martinez, 2016). 


\section{Methodology}

The information collected for the development of this document was obtained from bibliographical writings,. Under those circumstances, official pages of the Colombian State were consulted to focus research within the National Development Plan 2010-2014, specifically on the website of the National Planning Department -DNPand the National Administrative Department of Statistics -DANE-. Finally, documents, texts and research articles were investigated in national and international databases that have an agreement with the Universidad Libre and in the web pages of some of the programs and social projects developed in Colombia.

\section{Results}

\subsection{Objectives for reducing inequalities in Colombia}

Indeed, in the period corresponding to the application of the National Development Plan from 2010 to 2014, the poverty rate presented a reduction of 10 percentage points from $39 \%$ to $29.3 \%$ and extreme poverty fell from $13.5 \%$ to $8.6 \%$. This meant that 2.4 million people came out of poverty and 1.5 million from extreme poverty (Departamento Nacional de Planeación, 2014 ).

According to data presented by the DANE (2014) and expressed in the National Development Plan 2010-2014, in Colombia's departments, there were wide differences; highlighting the levels of poverty incidence in one of the departments, Chocó . This kind of differences in the level of poverty throughout Colombia can be explained by its diversity, because it is multi-ethnic country, geographically and territorially complex, being these characteristics particularly demanding when heading to the equity path in the country. However, thanks to the economic performance observed since 2002 accompanied by an increasingly solid social policy, Colombia has made unprecedented progress in equity and poverty reduction, particularly, in the period 2010-2014.

$1 \%)$, Cauca (58,4\%), La Guajira $(55,8 \%)$ and Córdoba $(51,8 \%)$ and well above the national average $(30,6 \%)$, in contrast to Bogotá, Cundinamarca and Santander that register poverty rates below 20\%. (El Departamento Administativo Nacional de Estadistica (DANE, 2014).

It is worth highlighting that one of the factors that influences the Reduction of inequalities is the Information and Communication Technologies (ICT), which are determinants in social and economic equity, since they allow the development of productive potentials and activities to improve the quality of life on individuals and regions (Tedesco, 2005).

Between 2010 and 2014, important advances focused on ICT infrastructure and services were achieved, mainly represented by a coverage of $96 \%$ of head-municipalities, approximately 5000 community centers for internet access and the allocation of more than 1.5 million subsidies for internet connection in strata 1 and 2 (Dinero, 2006). However, significant voids are still being identified in the access, use, and appropriation (Departamento Nacional de Planeación, 2014 ).

The National Development Plan (2010-2014) mentions that the objectives for an equitable Colombia without extreme poverty, developed through targeted public expenditure, were the following:

- Eradication of extreme poverty in and reduction of moderate poverty: Focused on strengthening the articulation, coordination and evaluation of the offer in social protection and promotion programs, developing an updated and detailed databases of social programs available at national, departmental and municipal levels.

- Reduction of income population gaps: To promote the generation of income of the poorest population through the creation of quality employment, entrepreneurship, the consolidation of 
inclusive productive projects and financial inclusion through the integration of contributory regimes and subsidized, and increase productivity to accelerate economic growth.

- Reduction of population and territorial gaps in the provision of quality services in health, education, public services, infrastructure and connectivity: To develop this objective, the Cero $a$ siempre model of comprehensive early childhood care was implemented, which promotes and guarantees the integral development of girls and boys from gestation to six years old, including the Public Policy of Disability and Social Inclusion to reduce inequalities and generate quality opportunities, with accessibility and population acceptance.

On the other hand, in order to facilitate quality access in basic, middle and tertiary education, the expansion of quality coverage at the aforementioned levels, seeking an increase in educational coverage and closing gaps between rural and urban areas, in this order of ideas it can be mentioned the National Plan of Educational Infrastructure 2015-2018, which has identified the need for 30.693 classrooms to promote the establishment of a single studying day of education for every student, in contrast to the application of two different studying days divided in the same classroom (Ministerio de Educación, 2015).

- Promotion of the inclusive economic development of the country and its regions: to implement the Productive Development Policy with the objective of promoting productive diversification between the labor market and social protection. The above focuses on strategic sectors to generate new companies and business lines that involve the value chain and promote the generation of employment in the poor and vulnerable population.

\subsection{Programs and projects focused on reducing inequalities during 2010-2014 period}

\subsubsection{Programs and projects in education}

The programs related to education started by stablishing a network of protection against poverty that proposed to serve approximately 1.5 million families in extreme poverty. This strategy seeked to fulfill, through the program known as "Familias en acción" (Families in Action) and from the goal planned by the government that the subsidized were concentrated in the same place, that is, that they did not irrigate across the country. In addition to this, an analysis by conceiving the family as a whole started to be done by leaving behind the previous unit of analysis that was only focused on the individual. (Ministry of Education, $s / f$ )

In effect, Familias en Acción provided all poor and extremely poor families who have children and adolescents with different economic incentives to complement their income. An example of this was the incentives that were delivered in education and health, complying with the following conditions: The education incentive was given to 3 children or adolescents who were between the ages of 4 and 18 who were in the school system, in addition to this condition, they had to fulfill two commitments such as: Attending at least $80 \%$ of the scheduled lessons, and not failing more than two scholastic years; while on the health incentive side, one was given for each family for all children under 6 years age twice a year, every six months, until the day before the children reach 6 years of age, and being suppressed in case they do not attend opportunely to the appointments of integral valuation in the IPS that correspond to them (Alcaldía Distrital de Santa Marta, s/f)

In addition to this, Families in Action determined the basic needs of the family nucleus as an essential part of human capital, monetarily accompanying families, and training future participants in the labor market to develop a decent life project with better opportunities. Families are like a seed, which, if it will be sown and cultivated properly, it will produce great achievements.

However, the maintenance of this expense is increasing due to a large number of people who register without having the status of poor or vulnerable population, and another really important problem is the abuse of the 
system by a certain beneficiary population that is currently dedicated solely to receiving the subsidy and does not generate additional income through the formal labor market, but they increase labor informality (Departamento de Prosperidad Social, 2016).. What is more, in extreme cases, some people live only from what is received periodically through this program. In addition, they are not contributing productively to improve their living conditions, but rather they are absorbing state resources, which come from taxes, paid by the inhabitants of the national territory and they could also be used in other economic development provisions. The execution of this program has allowed an important percentage of the population to be removed from their poverty status in economic growth figures. However, it should be note that, under development conditions, this program has not been able to reduce social voids in the country (Betancourt, 2018).

Another program is the "Cero a Siempre" policy that materialized through Law 1804 of 2016, and the Colombian Family Welfare Institute, in order to ensure that the processes of each of the integral care services have the processes permanent training and accompaniment to families that also seeks to enhance the promotion of integral development by putting the family in the leading role of mental and physical development of children (Gobierno de Colombia 2018).

Then, when a child between zero and six years of age does not receive the necessary resources constantly, it will be very difficult that, in the first instance he/she can survive to the social and economic conditions during the first years of life, though it should be noted that infant mortality has reduced in the country. Another important factor is the family environment; in many cases, a dysfunctional environment does not allow the free development of the child and sometimes he/she does not receive the necessary food for physical development and disease prevention. As second instance, it can generate in the adult, personal gaps that limit opportunities in such a demanding society and lead to inappropriate social behaviors that degrade the human being. With this in mind, the execution of this program is highlighted as it supports basic aspects such as education and health, and in relation to the other social programs of the government, it can contribute to generating more benefits to improve the quality, because of the demographic conditions, in many cases the resources don 't arrive or there is not inclusion to populations far from urban centers (Tassara, 2015)..

Likewise, the Jóvenes en acción (youth in action) program has shown good results, considering that it has allowed the insertion of many young people with limited resources to higher education, creating new opportunities to improve the quality of life and income through the labor market with a focus open and innovative promoting the development of own initiatives. Nevertheless, in reality the program has certain shortcomings by focusing solely on the population of the lower state, without taking into account the middle class, which has always carried the entire tax burden and they usually are the least favored.

On the other hand, strict monitoring and control of the allocation of resources must be carried out where efficient use and distribution of these revenues is guaranteed, and the government should implement future requirements that contribute to the growth and development of the regions to become more productive and competitive in the country; for instance, a student from a rural area or a town far away from urban centers obtains the benefit from Jóvenes en acción (youth in action), and then conducts all his/her studies properly by achieving an efficient professional profile, not returning to his/her place of origin to contribute based on what he/she has learned and to strengthen the development of that area. On the contrary, the individual stays in the city considering the best opportunities, but in a not-so-extreme case, he/she ends up working in another function very different from what he/she studied (Cano, Castillo y García, 2016),.

Regarding the strategies that tackled income generation and prolonged operation of relief and recovery, it can be said that they were very concrete projects that focused on populations with high rates of social inequality such as women and indigenous groups, and also develop their plans within an integration framework so that women and indigenous people have more opportunities; the aforementioned figures are highlighted on the 
financial pyramids of women, in which the concepts of savings and credit are demonstrated (González y Saenz, 2018). .

Finally, it can be said that these strategies could be used by the government in joint work with the other economic agents (companies and families) in specific regions, where educational aids are not received to contribute to the financing entrepreneurship projects and the particular development of a population, since it must be understood that each place comprises a different environment.

\subsubsection{Programs and projects in health}

On the other hand, the national government during 2010 and 2014 carried out various projects to break down health inequality, creating the "Sistema General de Seguridad Social en Salud-SGSSS"(General System of Social Security in Health) that rules the access to health services in Colombia. Rural and urban populations have access to health services based on two affiliation regimes: the contributory scheme that covers employees and independent workers, who contribute part of their salary to receive basic health services, and in the second instance is the subsidized regime that is the one that is destined for the most vulnerable population. Currently, it estimated that in Colombia more than 42 million people are active in the health affiliation system (Ministerio de Salud y Protección Social, 2017).

Specifically, for the rural sector, it has been assured that one of the main problems is related to productive and social exclusion by configuring a dynamic of inequality; an example of this is how the independent or selfemployed workers correspond to $51 \%$ of the rural population and their income does not reach a minimum wage; therefore, the only possibilities they have to access to the health services is through the subsidized regime. Under these conditions, it has been claimed that $69 \%$ of the employed rural population is dependent on the subsidized health system (Rodríguez Triana \& Benavides Piracón, 2016).

In order to achieve greater coverage in the subsidized regime, the government defined a new methodology for the send fase of a targeting instrument called the Beneficiary Selection System for Social Programs (Sistema de Selección de Beneficiarios Para Programas Sociales-SISBEN) that had existed since 1994; this instrument allows the identification of the least favored population and makes use of tools to measure the socioeconomic conditions of individuals to perform an individual selection and thus it will be able to identify the poor population. SISBEN grants health subsidies, scholarships, public jobs, among others since 1994; it grants a score called "SISBEN score" in which the population is classified into 6 levels (level 6 being the richest); this score is based on a collection of information with various characteristics from several households that were interviewed (Bottia, Cardona Sosa, \& Medina, 2013).

According to National Planning, currently, 36.2 million Colombians are in this system. The serious thing is that almost half of them are people who appear with low scores and access to subsidies instead of those who need it the most. Consequently, there is a process of debugging the database for three years and the current list will lose its validity at the end of 2019 (Hernández, 2018).

The new database locared in stratum number one, two, and part of them, in number three in the urban and rural areas. Amongs the identification ninetyseven thousand people who earn more than 3.8 million pesos per month were identified; now, they could be excluded from it and the new information will have 24 databases to validate the subsidized information (Canalrcn.com, 2019).

The health care sector contributed the most to the reduction of multidimensional poverty in Colombia between 2010 and 2016. Four of the 12.6 percentage points of decrease are attributable to the improvement in access to health services and to the growing financial assurance in population health (Ramírez, Bedoya y Díaz, 2016). 
The National Demographic and Health Survey (2016) evidenced a substantial decrease in infant mortality of four percentage points in the previous five years; on the other hand, the National Survey of Quality of Life for 2016 revealed that $75 \%$ of Colombians rate their personal experience in health as good or excellent (Ministry of Health and Social Protection of Colombia, 2017).

The health care system in Colombia has undergone different structural changes with the aim of improving service, coverage, and quality. The above in order to reduce the inequality of benefits for the different regions of the country, especially between two areas: the rural and urban ones.

For many years, the living conditions of the rural population has been highly lower than those from the urban area, not only in aspects of health but also in housing, public services, road infrastructure and educational infrastructure, among other. However, the main issue focuses on the poor health infrastructure, that is, hospitals with both builed capability and trained personnel to deal with all types of medical conditions, emergencies, surgeries, as well as laboratories and pharmacy, and even dentistry services.

The SISBEN has been created for the purpose of expanding coverage in the health care system. This system allows people with low incomes to belong to the subsidized regime (González y Saenz, 2018). However, a common problem with this program consists in the constant affiliation of people who are not in precarious conditions and pretend to, just to benefit from the health care system free of charge despite having sufficient income to be a part of the contributory regime; this situation generates a surcharge to the state budgets to cover the costs generated by the provision of the service in hospital and clinical centers, this problem generates a circle where the state does not pay the debt to the hospital, therefore, they could not continue benefiting people as the resources do not meet the needs of local workers, then this would result in suspension of service to subsidized beneficiaries.

Likewise, it can be said that some of the people who are affiliated with the subsidized regime also benefit from programs such as Familias en acción, a situation that directly affects the development of the economy, since these people are mostly not performing any formal productive activity that remunerates the value of the cost generated by its maintenance in the state accounts and in the economic growth of the country (Benjumea, 2017).

Now, moving on to another matter, the World Bank (2016) proposed the following high impact strategies in the fight against extreme poverty. The policies to increase the income of the poor, the increase in the access to essential services and the improvement of their long-term development prospects that are developed in Colombia with the 2030 objective as follows:

1. Early childhood development and nutrition: these measures help children during the first 1.000 days of life for nutritional deficiencies so as not to cause lower school performance.

2. Universal access to quality education: although access to education has improved in recent years, it is now necessary to ensure that all children receive quality education.

3. Universal health coverage: According to the World Bank, coverage of affordable and timely health care services reduces Inequality and at the same time, it increases people's ability to learn, work and progress.

4. Progressive taxation: equitable progressive taxes allow the financing of Government Policies and programs that are necessary to transfer resources to the poorest inhabitants. Likewise, tax systems could be designed to reduce Inequality while maintaining efficiency costs at a low level.

5. Rural infrastructure: the construction of rural roads reduces transportation costs, connects farmers with markets, and promotes access to schools and health care centers. 
In relation to the above, the country has been seeking the empowerment of the family nucleus in aspects of the fight against poverty that include factors such as employment, business development and education. In order to fulfill the proposal, the Government implemented the "Social Income" program, which provides incentives for Network United Families to acquire skills and competencies that generate work habits and teamwork in order to generate higher income. This program responds to what was stated in the National Council on Economic and Social Policy, through a document known as CONPES 3616, which points out that labor difficulties stem from the lack of capacity to be linked to a paid occupation (Departamento de Prosperidad Social, 2016).

The situation of Afro men and women in Colombia is different compared to what is stated in the Political Constitution of Colombia; The historical neglect of the State towards Afro-descendant groups and indigenous groups has generated vulnerability of fundamental rights, translating it into high levels of Inequality, marginality and discrimination, adding into the social context of armed conflict. Although it has been sought to promote equality and equity through different articles and laws, the reality is that the areas where Afro-descendants and indigenous people live in greater proportion are in an economic context with low economic development, that is, they aren't met. The social, economic, and environmental policies that contribute to the normal functioning of the economy and deprive in some way the right to meet the basic needs of the population (Iza Certuche, 2018).

Policies aimed at the Afro-Colombian and indigenous population are characterized by their institutional dispersion, given to the fact that they are formulated by various entities at national, departmental and municipal levels, without any instances of coordination between them. In Colombia, there are not independent and specialized institutions for the promotion and protection of human rights, the fight against racism and racial discrimination, as Durban's statement suggests. Nor has Colombia formulated a national program of Action against racism and discrimination that establishes coordination mechanisms between the entities involved and their actions (Rodríguez Garavito, 2009).

Since the 1991 constitution, Afro-descendant populations began to be recognized within the public and legal order of society after having passed a national history full of racism and exclusion; however, there is still a national struggle for an equality with this racial group, given that the cultural and structural racism that exists is difficult to eradicate in Colombia.

Although this situation has gradually improved as the global environment has eliminated barriers and social stereotypes, fostering respect for differences, it can be said that it is now easier to recognize sexual differences than racial conditions in terms of their forms of act or physical appearance, since sometimes words or nicknames such as black, niche, Indian are used, although the person who says it does not believe that it affects them, if they do so psychologically and make them believe that equality will never be achieved.

In school and at-home education, the love and respect for equality are promoted since childhood, however, the state must implement more programs and projects that dignify the ethnic and racial groups of the country, since it cannot be forgotten that they were the first societies that built the foundations of today's society. It must also focus social policies and municipal development plans on the development of the living conditions of these groups because they are Colombians with greater Inequality in economic resources, housing, transportation, food, public services, health services, road infrastructure, conditions dignified labor, and violation of Human Rights (Iza Certuche, 2018).

It is the duty of the state to ensure the good development of what is established in the Political constitution and at all times by taking into account that in any case, public and social spending will be a priority; so that inequality gaps can be reduced that are not allowing to have a more efficient, better developed and more competitive and productive country, and therefore with greater economic growth. 
In terms of education, according to statistics from the Organization for Economic Cooperation and Development (OECD) in 2017, Colombia uses less spending for elementary students than Mexico, Argentina, Brazil and Costa Rica, and less than all members of The OECD since Colombia invests approximately $\$ 2,490$ to purchasing power parity per elementary student while the OECD average is $\$ 8,733$. In secondary and middle education, Colombian spending is $\$ 3,040$ per student, while the OECD average is $\$ 10,104$

On the other hand, the positive correlation between educational spending and academic performance is analyzed, a situation that causes Colombia to obtain very low scores in the PISA tests, which were below the average of the OECD countries; in 2014, Colombia ranked 57 in science, 54 in reading comprehension and 41 in math, among 70 countries.

Finally, it can be said that important changes were generated during the execution of the plans for the eradication of poverty, with the main factor being public expenditure, which was allocated through budgets for the development of Government programs suchc the 2010-2014 plan, mainly focused on education, health, housing and subsidies.

According to the Organization for Economic Cooperation and Development (OECD), the Colombian government spends $5.4 \%$ of GDP on health and individuals $1.8 \%$; in the OECD they spend $6.5 \%$ and $2.5 \%$ respectively. In 2017, Colombia has shown notable changes in health care coverage, in which approximately $96.6 \%$ of the population is insured, thus demonstrating a significant indicator in relation to the other OECD countries.

Expenditure on housing programs represented $2.6 \%$ of social expenditure, equivalent to approximately 1.8 billion pesos. However, the impulse to different housing programs is not significant in social spending as a whole. These programs include 100 \% Subsidized Housing Program, Family Housing Subsidy and "Mi casa ya" program (Espitia et al., 2019).

\section{Conclusions}

In recent years, Colombia has evolved steadily compared to other countries. The aspect that has been most characterized is health within the high coverage margins, achieving almost the entire population with health coverage. Regarding the country's development expectations, Colombia seeks to meet the objectives stipulated in the various international summits in order to contribute to the reduction of internal inequalities in the country and the rest of the world, as well as contributing to the efficient performance of the other sustainable development goals.

The different programs aimed at reducing poverty should ensure that many households that were previously in a situation of multidimensional and monetary poverty do not return to be again, concentrating all efforts to reduce the likelihood of falling back into poverty, generating a prevention measure in which a more dynamic and diversified environment is created in the economy to promote decent employment, the incentive to strengthen the business network, adequate training by competition according to labor demand, inequality in distribution of income, create greater coverage in the allocation of resources (public goods) to individuals and families, in addition to facing the migratory flow in the different locations of Colombia, without discriminating according to gender or race, among others, in order to improve the quality of life of all citizens.

On the other hand, the national government must focus the social programs towards a definitive reality and not only to comply with the reduction of the figures that are reflected in economic growth and little internal development, it must also propose greater policies for control and surveillance of budgets of each project or program to make proper and efficient use and have a positive effect in the near future. 
Generally, when it comes to government to intervene in the economy through taxes and social spending, it causes decrease on the inequality, however, in Colombia when the government intervenes, what it conceives is that inequality remains almost the same without causing any significant change, leading to the conclusion that both fiscal and social policies are not designed to end or reduce inequialities in the country and therefore need to be redesigned or modified so that they become effective. With this been said, the state must redirect laws, programs and projects that aim to improve the coverage and quality of the health care system in the country; despite some efforts in infrastructure investment and capital investment, there have not been positive results because constantly there are problems with patients and the state is not focusing budgets on new public health care centers, but they rather prefer paying for health services in private institutions.

The way in which taxes are collected and how the public budget is spent is one of the ways to discover why Colombia is not able to end the inequality. People's reference about the country where they live, can be very misleading and far from reality as inequality is not being perceived; the inhabitants only assume that others live in a similar fashion to theirs, they believe that everyone can get a house, prepare dinner and pay the different bills they have, but unfortunately that is not true, a large part of the Colombian population only have one meal per day while others have five.

Although the programs aimed at reducing poverty and the actions and policies that the country has taken to reduce inequalities that have had some good results, continuous accompaniment and day to day strengthening of these needed. Having an economic growth of the country does not mean having a reduction in the inequality of its inhabitants and this is due to the fact that economic indicators can show growth at the same time that social reality yields results of wealthy people compared to poor ones.

From the economic point of view, Colombia has not given sufficient priority or importance to the issue of inequality; Over time the different government plans looking for solutions, however, they create programs that do not have efficient control and although the results they give to the public are positive figures, it does not show that people in conditions of poverty or vulnerability, they really overcome the economic and social situation in which they find themselves; this situation can be evidenced day by day as a part of Colombia's population is increasingly concentrating wealth on that small percentage of the population but at the same time, the quality of life of most of the population deteriorates through years. In addition to this, all indicators and all programs created only to determine a standard survival situation, do not really determine social development or guarantee quality of life.

In conclusion, inequality is a problem that does not end with the creation of a wide variety of subsidiary programs for the vulnerable population because through these programs, only the development of a third of the population is promoted, but as a whole, leaves away the entrepreneur that gives employment as the employee that offers labor, these facts may give a more equitable environment and with better conditions not only economic for the population, an example of this is; decent employment with fair wages. In Colombia, the two essential pillars are education and social spending to reduce the gap in both income and opportunity communities, but in their inconsistencies, there are the so-called "actors" that enter the system as people with limited resources in subsidy programs of higher education and health, causing the need to be taken away from people in need and because of a lack of understanding are not included in these programs, the monitoring of these subsidies should be managed properly since such programs would not indicate improvement if the wealthy people remain rich, and the poor people poor.

\section{Bibliographic references}

Alcaldía Distrital de Santa Marta (s/f). Actualización escolar de beneficiarios de 4 a 18 años del programa más familias en acción. Santa Marta: Distric Mayor of e Santa Marta. Retrieved from 
https://www.santamarta.gov.co/tramites-y-servicios/actualizacion-escolar-de-beneficiarios-de-4-18-anosdel-programa-mas-familias-en-accion

Benjumea Zapata, F. J. (2017). Estratificación socioeconómica y sisbén en Colombia la focalización de la focalización del gasto social (Master's thesis, Maestría en Planificación y Administración del Desarrollo Regional).

Betancourt, V. A. (2018). Condicionar, focalizar e Invertir en capital humano: El programa" Familias en Acción" o la receta internacional de lucha contra la pobreza para Colombia. Panorama Económico, 26(1), 43-64.

Bottia, M., Cardona Sosa, L., \& Medina, C. (2013). El SISBEN como mecanismo de focalizacion individual del ' regimen subsidiado en salud en Colombia: ventajas y limitaciones. Revista de Economía del Rosario , 137177. Retrieved from https://revistas.urosario.edu.co/index.php/economia/article/view/2820

Canalrcn.com. (2019, March 10). El lunes, empieza la encuesta del SISBEN en Bogotá. Noticias RCN, p. 1. Retrieved from https://noticias.canalrcn.com/nacional-bogota/este-lunes-inicia-bogota-encuesta-delsisben

Cano, C. A. G., Castillo, V. S., \& García, L. E. T. (2016) Análisis del impacto del Programa Jóvenes en Acción de la Universidad de la Amazonia período 2014-2015. RevistaFACCEA 6 (1), pags. 58-69

Cantú Martinez, P. C. (2016). The new challenges of sustainable development by 2030. Ciencia UANL, 6. Retrieved from http://eprints.uanl.mx/11001/1/Documento6.pdf

Gobierno de Colombia (2018). Informe de rendición pública de cuentas en primera infancia 2012-2017. Government of Colombia. Bogota D.C: Government of Colombia. Retrieved from http://www.deceroasiempre.gov.co/Prensa/CDocumentacionDocs/INFORME_DE_RENDICION_PUBLICA_D E_CUENTAS_EN_PRIMERA_INFANCIA_2012-2017.pdf

Departamento de Prosperidad Social (2016). What is social income? Prosperidad Social. Bogota D.C : Departamento de Prosperidad Social. Retrieved from https://www.prosperidadsocial.gov.co/que/fam/Paginas/IngresoPS.aspx

Departamento Nacional de Planeación (2014). Bases of the National Development Plan 2014-2018. Bogota D.C: Minagricultura. Retrieved from https://www.minagricultura.gov.co/planeacion-controlgestion/Gestin/Plan de Acción/PLAN NACIONAL DE DESARROLLO 2014 - 2018 TODOS POR UN NUEVO PAIS.pdf

Dinero (2006, October 17). New plan to attack poverty launched today the Government. Dinero.com. Retrieved from Dinero: https://www.dinero.com/actualidad/noticias/articulo/nuevo-plan-para-atacar-pobrezalanzo-hoy-gobierno/37637

Departamento Administativo Nacional de Estadistica (DANE). (2014). Monetary Poverty 2014. Bogota D.C: El Departamento Administativo Nacional de Estadistica (DANE). Retrieved from https://www.dane.gov.co/files/investigaciones/condiciones_vida/pobreza/cp_pobreza_departamentos_R 2013.pdf

Espitia, Jorge, Ferrari, César, González, Jorge Iván, Hernández, Isidro, Reyes, Luis Carlos, Romero, Alejandra, Tassara, Carlo, Varela, David, Villabona, Jairo, \& Zafra, Gustavo. (2019). El gasto público en Colombia. Reflexiones y propuestas. Revista de Economía Institucional, 21(40), 291-326. https://dx.doi.org/10.18601/01245996.v21n40.11 
González Guzmán, I. A., \& Saenz Benavides, N. V. (2018) La política pública de subsidios en el estado social de derecho y sus problemáticas. Recuperado de: http://hdl.handle.net/11634/16068

Hernández Luque, L. A. "Pobre pobre, no... pero tampoco rica" Representaciones y subjetividades en la experiencia de ser sisbenizado (Doctoral dissertation, Universidad Nacional de Colombia-Sede Bogotá).

Iza Certuche, M. F. (2018). Intersectionality and the construction of territorial peace in Colombia: a case analysis of the women of Buenaventura . Ciudad Paz-Ando, 18-26. Retrieved from https://revistas.udistrital.edu.co/index.php/cpaz/article/view/13757/14219

Ministerio de Salud y Protección Social. (2017). Health sector, the one that contributed most to poverty reduction. Bogota D.C: Ministeria de Salud y Protección Social (Minsalud). Retrieved from https://www.minsalud.gov.co/Paginas/Sector-salud-el-que-mas-contribuyo-a-reduccion-de-pobreza.aspx\#

Rodríguez Garavito, C. (2009). racial discrimination in Colombia: alternate report to the UN committee on the Elimination of Racial Discrimination- CEDR- 2009. Uniandes, 10. Retrieved from https://www.dejusticia.org/wp-content/uploads/2017/04/fi_name_recurso_206.pdf

Rodríguez Triana, D., \& Benavides Piracón, J. (2016). Health and rurality in Colombia: an analysis from the standpoint of the social determinants of health. Revista Facultad Nacional de Salud Publica, 13. Retrieved from http://www.scielo.org.co/pdf/rfnsp/v34n3/0120-386X-rfnsp-34-03-00359.pdf

Tassara, C. (2015). Pobreza y desigualdad en Colombia: análisis del Plan Nacional de Desarrollo 2014-2018. Carolina Isaza (Editora). Anuario "Seguimiento y análisis de políticas públicas en Colombia”. Bogotá: Universidad Externado de Colombia: Centro de Investigaciones y Proyectos Especiales (CIPE).

Tedesco, J. C. (2005). Las TICs y la desigualdad educativa en América Latina. Presentado en el Tercer Seminario Las Tecnologías de Información y Comunicación y los Desafíos del Aprendizaje en la Sociedad del Conocimiento, realizado entre el, 30.

United Nation Development Programme (2015). What are the sustainable Development Goals? New York: United Nation Development Programme (UNDP). Retrieved from https://www.undp.org/content/undp/en/home/sustainable-development-goals.html

United Nations Development Programme (UNDP). (2016). Goal 10: Reduced Inequalities. New York: United Nations Development Programme (UNDP). Retrieved from https://www.undp.org/content/undp/en/home/sustainable-development-goals/goal-10-reducedinequalities.html

Vergara Tamayo, C. A., \& Ortiz Motta, D. C. (2016). Sustainable development: approaches from economics . Apuntes del CENES, 15-52. Retrieved from http://www.scielo.org.co/pdf/cenes/v35n62/v35n62a02.pdf

Esta obra está bajo una Licencia Creative Commons Attribución-NoCommercial 4.0 International

(cc) BY-NC 